\title{
The Effect of Peer Review on Writing Skill of EFL Students
}

\author{
Nasrin Shokrpour, \\ Shiraz University of Medical Sciences, Shiraz, Iran \\ Nikta Keshavarz, \\ Freelance, Iran
}

\section{Seyed Mohammad Jafari}

Shiraz University of Medical Sciences, Shiraz, Iran

\section{Introduction}

Of the four language skills (reading, speaking, listening, and writing), writing skill has, for a long time, been underestimated (Dempsey, Pytlikzillig \& Burning, 2009; Gao 2007; O'Muircheartaigh, 1990). On the other hand, it is suggested that the traditional teacher feedback on students' writing yields meaningless and unproductive results (Kim \& Kim, 2005). In a study conducted on Korean students, Rollinson (2004) found that being traditionally accustomed to receiving specific instruction from teachers causes the students to write for the teacher, not for themselves, and the teacher is their only audience. Teachers will also become overwhelmed by the task of giving feedback and correcting the students' writing. It was also shown that feedback is more useful between drafts, and little improvement is made when it is done at the end of the task. Reichelt (1999) points out that the teachers are uncertain about the role of writing in EFL classrooms. In her survey, she found that articles on FL writing appeared in publications addressing FL professionals, suggesting that many of those engaged in FL writing research and pedagogy see themselves as primarily language teachers rather than writing teachers. Due to the fact that in traditional writing classrooms students are passive in the classroom, they naturally feel uncomfortable with cooperative interaction methods that require them to take a more active role.

With the breakout of interactive writing methods, student writers will gain selfconfidence, fluency and autonomy, and will be stimulated to express their own 
authentic voices in the process of text product (Tribble 1996). However, a major issue that has not been adequately addressed is peer response in EFL writing classrooms (Ali-Grami, 2010; Hedge, 1988; Raimes, 1993; White \& Arndt 1991). Most of the studies on the effect of peer response come from ESL context (Kamimura, 2006) and raise the question if EFL learners behave similar to ESL students in a peer review setting (Levine, Oded, Conor \& Asons, 2002). ESL is typically taught in the immersion context, where English is the language of the environment. However, EFL learners mostly learned English in the classroom (Levine et al, 2002).

Peer review is increasingly conducted in writing classes since the prevalence of communicative approach in recent years, and it has been proved as an effective approach to improve the writing skill (Corbin, 2012), to increase motivation to writing, and to learn how to treat writing as a collaborative social activity (Farrah, 2012). Therefore, this study was conducted to contribute to the Iranian EFL community, in particular, and to all EFL students, in general. Peer review can be a way to open up new possibilities for both writer and reviewer.

\section{Literature Review}

"The process approach treats all writing as a creative act which requires time and positive feedback to be done well (Rollinson, 2004)." In process writing, the teacher moves away from being someone who sets students a writing topic and receives the finished product for correction without any intervention in the writing process itself. Research shows that feedback is more useful between drafts (Rollinson, 2004). Corrections written on compositions returned to the student after the process has finished seem to do little to improve their writing skill. According to Rollinson (2004), ideas on the constructive effect of peer review has seemed to be busy work or a waste of time while others consider it as an important learning experience. "The opponents of peer review argue that providing negative criticism has the risk of irritating or offending the writer. Students might also have difficulties identifying problem areas in other students' writing and offer them inaccurate or misleading advices (Horowitz, 1986). Similarly, writers may react negatively and defensively to critical comments from their peers (Amores, 1997). But studies looking specifically at the kinds of advice given by peer editors have found relatively small amounts of miscorrection. It is suggested that reviewers, for example, are more likely to address surface errors than problems of meaning Keh, 1990) and that inexperienced L2 students may find it hard to judge the validity of their peers' comments (Leki, 1990). Peer response studies have focused on the nature of peer interactions in writing workshops (Guerrero and Villamil, 1994; Lim and Jacobs, 2001; Ohta, 1995). On the contrary, Caulk (1994) concluded that L2 
peer commentary appeared to offer valuable and complementary suggestions when compared with teachers' comments, with only six percent of peer suggestions offering bad advice. The comments covered different concerns like those of the teacher comments and were more specific than general (also see Jacobs, 1989).

Taken for granted the fact that feedback is an important part of every language teaching and learning process, careful work on the job will be a contribution to pedagogy (Hedge, 1988; Raimes, 1993; White and Arndt, 1991). Peer feedback has recently drawn the researchers' attention around the world and many of them have started to research on it. In fact, over the past twenty years, changes in writing pedagogy and research have transformed feedback practices, with teacher comments often supplemented with peer feedback, writing workshops, conferences, and computer-delivered feedback (Hyland and Hyland, 2006). Sengupt (2000) found that through using peer feedback, the responsibility moved gradually from the teacher to peer, and finally, to the students themselves. A posttest composition at the end of the year showed that the two revising groups had made more progress than the traditionally taught group. Likewise, Hedgcock and Lefkowitz (1992) found that the responsibility of feedback moves gradually from the teacher to the peer and finally to the students themselves. A post-experimental questionnaire and interview also showed that the students appreciated much of what they had learned because this experience had taught them about how teachers think and the instruction had helped them to succeed and gain a new conception of what writing involved.

Berg (1999) conducted an experimental study to investigate how trained peer response shapes ESL students' revisions and revision quality. It was concluded that trained peer response did exert positive impact on ESL students' revision types and quality. In his study, Harmer (2004) observed that trained students incorporated a significantly higher number of comments. The number of peer-triggered revisions comprised $90 \%$ of the total revisions, and the number of revisions with enhanced quality was significantly higher than that before peer review training. $\mathrm{He}$ concluded that with extensive training inside and outside of class, trained peer review feedback can positively impact EFL students. Al-Jamal (2009) conducted an experimental study to investigate the impact of peer response on the writing skills of Jordanian EFL students. The findings revealed that the participants have benefited from the training on peer feedback.

Some teachers and writing theorists have fostered peer groups in high school and college classrooms as a way to encourage students to write and revise. As Moffett (1983) suggested, teachers teach students to teach each other. 
Some peer response studies have focused on the nature of peer interactions in writing workshops (Guerrero and Villamil, 1994; Lim and Jacobs, 2001; Ohta, 1995),. Hyland's (2000) examination of writing workshop interactions demonstrated that the aspects of peer feedback mentioned most positively by the students in interviews were related to informal peer support mechanisms. Rather than focusing on a finished product, these interactions functioned mainly at the affective level, with students informally providing each other with support and advice during the writing process.

Another line of research has focused on students' attitude of the peer response method. Exploring Students" attitude of the peer response experience has yielded contradictory results. Whereas Nelson and Murphy (1993) and $\mathrm{Hu}$ (2005) found that Chinese students welcomed peer feedback, other educators like Leki (1990) and Srichanyachon (2012) identified several shortcomings with peer feedback and concluded that students prefer teacher feedback as a more effective means of writing revision.

\section{Research Questions}

The current study investigated the possible effectiveness of the peer review technique to increase the quality of EFL learners' writing, and to see whether this method motivates student writers to write. Regarding the objectives of this study, two research questions are raised:

1- Does peer review technique help learners improve their writing skill?

2- Does peer review technique increase positive attitudes toward writing among EFL learners?

\section{Significance of the Study}

This study examines the effect of peer review on writing skill and is significant in the sense that:

1. The findings of the research yield both practical and theoretical results and can be applied to fields of language teaching particularly writing skill.

2. It promotes interaction and development. It is argued that students should be encouraged to act critically, cooperatively, and autonomously (Murphey, 2000). Peer response would help learner autonomy and it is possibly positive that the teacher is not always the only audience for the written work (O’Muircheartaigh, 1990). 
3. Peer review is effective since peers can oftentimes be a lot more honest with each other than with their instructor.

4. As social interaction is such a key component of the peer response process, perhaps EFL students with a common language and culture behave differently from the ESL students. One of the main pedagogical uses of peer review comment is its use as a tool to teach students how to do peer review.

\section{Methods}

\subsection{Data Collection Procedure}

Fifty intermediate female learners aged 17-24 years were selected from Bahar Language Institute in Shiraz, Iran, and were randomly categorized into two experimental and control groups.

To start, a pre-test of proficiency was given to both experimental and control groups. After that, the learners of both groups were asked to write their essays according to the instruction and writing guidelines and criteria they had already received. However, the learners in the experimental group were provided with an additional peer review instruction offered by O'Muircheartaigh (1990) including the provision of constructive feedback to their peers and evaluating and correcting the peers' performances. The experiment was run over a three-month period with the control group receiving feedback only from the teacher and the experimental group receiving peer feedback. The students were assigned to write about ten subjects of their interest out of a topic list including sixteen topics written in the writing part of their textbooks, New Interchange Two, Advanced Writing and Essay Writing, and submit one composition in each session. As the students of the experimental group completed their first drafts, they were paired for peer review and conferencing and were assigned to exchange their essays with those of their peers. The reviewers had to correct and evaluate the essays, and respond to them in a week. After doing the peer review, the instructor had learners meet their peers for peer negotiation and conference that they had already been taught in the peer review instruction session. Then, the reviewers presented their opinions towards the problems and mistakes they had encountered and made an argument with peers to get the problem solved. After the revision sessions, the student writers revised the essay implementing the peers' feedback. The students in the control group were traditionally handled in the classroom by the teacher who assigned them the homework and corrected them by herself, giving feedback to them the next session. Finally, at the end of the course, both groups were given the same posttests corrected by the instructor and one of the expert colleagues. The inter-rater reliability was measured and proved to be acceptable. At the end of the term, a 
survey assessed the students' opinions about specific aspects of the peer review method through a multiple-test questionnaire.

\subsection{Data Analysis}

First, the data were analyzed and expressed descriptively to provide evidence whether the peer review method cause any writing improvement in the writing of the experimental group through ten experiments.

\section{Results \& Discussion}

Table 1 indicates that there is some improvement in the writing of both groups, with the experimental group advancing more than the control group.

Table 1. Mean scores of the experimental and control groups in each factor

\begin{tabular}{|c|c|c|}
\hline Factor & Control & Experimental \\
\hline 1 & 15.96 & 16.20 \\
\hline 2 & 16.12 & 16.04 \\
\hline 3 & 16.16 & 16.64 \\
\hline 4 & 16.44 & 17.16 \\
\hline 5 & 15.48 & 16.72 \\
\hline 6 & 15.68 & 16.48 \\
\hline 7 & 16.16 & 17.44 \\
\hline 8 & 16.48 & 17.76 \\
\hline 9 & 16.24 & 17.80 \\
\hline 10 & 16.40 & 18.28 \\
\hline
\end{tabular}

Linear graph1 presents a clear description of the learners' performance of the two groups.

\section{Linear graph1. Description of the learners' performance of the two groups}

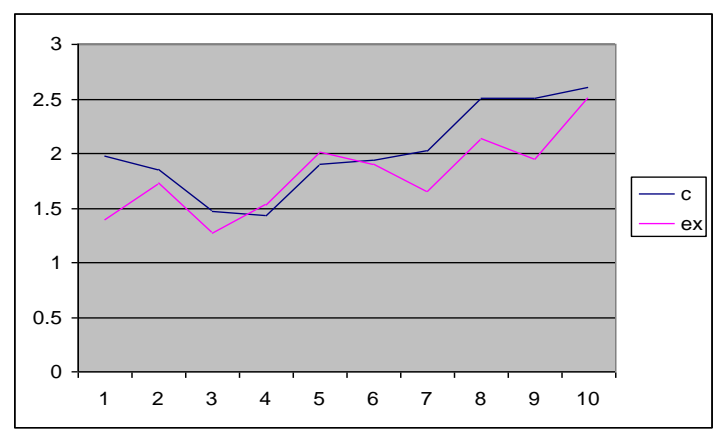


Table 2 further presents the difference observed between the performance of the two groups in terms of means and standard deviation.

Table 2. The total score for the means and the standard deviations

\begin{tabular}{|c|c|c|c|c|}
\hline \multicolumn{2}{|c|}{ GRP } & Mean & Std. Deviation & $\mathrm{N}$ \\
\hline $\mathrm{C} 10$ & \multirow{3}{*}{1.00} & 18.28 & 1.400 & 25 \\
\hline \multirow{2}{*}{$\begin{array}{l}2.00 \\
\text { Total }\end{array}$} & & 16.40 & 1.979 & 25 \\
\hline & & 17.34 & 1.944 & 50 \\
\hline C9 & & 17.80 & 1.732 & 25 \\
\hline \multirow{2}{*}{\multicolumn{2}{|c|}{$\begin{array}{l}2.00 \\
\text { total }\end{array}$}} & 16.24 & 1.855 & 25 \\
\hline & & 17.02 & 1.943 & 50 \\
\hline \multicolumn{2}{|c|}{$\mathrm{C} 8 \quad 1.00$} & 17.76 & 1.268 & 25 \\
\hline \multirow{2}{*}{\multicolumn{2}{|c|}{$\begin{array}{l}2.00 \\
\text { total }\end{array}$}} & 16.48 & 1.475 & 25 \\
\hline & & 17.12 & 1.507 & 50 \\
\hline \multicolumn{2}{|c|}{$\begin{array}{ll}\mathrm{C} 7 & 1.00\end{array}$} & 17.44 & 1.530 & 25 \\
\hline \multirow{2}{*}{\multicolumn{2}{|c|}{$\begin{array}{l}2.00 \\
\text { total }\end{array}$}} & 16.16 & 1.434 & 25 \\
\hline & & 16.80 & 1.064 & 50 \\
\hline \multicolumn{2}{|c|}{ C6 $\quad 1.00$} & 16.48 & $2 . .014$ & 25 \\
\hline \multirow{2}{*}{\multicolumn{2}{|c|}{$\begin{array}{l}2.00 \\
\text { total }\end{array}$}} & 15.68 & 1.909 & 25 \\
\hline & & 16.26 & 2.028 & 50 \\
\hline \multicolumn{2}{|c|}{$\begin{array}{ll}\mathrm{C} 5 & 1.00\end{array}$} & 16.72 & 1.904 & 25 \\
\hline \multirow{2}{*}{\multicolumn{2}{|c|}{$\begin{array}{l}2.00 \\
\text { Total }\end{array}$}} & 15.48 & 1.939 & 25 \\
\hline & & 16.10 & 2.003 & 50 \\
\hline \multicolumn{2}{|c|}{$\begin{array}{ll}\mathrm{C} 4 & 1,00\end{array}$} & 17.16 & 1.650 & 25 \\
\hline \multirow{2}{*}{\multicolumn{2}{|c|}{$\begin{array}{l}2.00 \\
\text { total }\end{array}$}} & 16.44 & 2.022 & 25 \\
\hline & & 16.80 & 1.863 & 50 \\
\hline \multicolumn{2}{|c|}{ C3 $\quad 1.00$} & 16.64 & 2.139 & 25 \\
\hline \multirow{2}{*}{\multicolumn{2}{|c|}{$\begin{array}{l}2.00 \\
\text { total }\end{array}$}} & 16.16 & 2.511 & 25 \\
\hline & & 16.40 & 2.321 & 50 \\
\hline \multicolumn{2}{|c|}{$\begin{array}{ll}\mathrm{C} 2 & 1.00\end{array}$} & 16.04 & 1.947 & 25 \\
\hline \multicolumn{2}{|c|}{2.00} & 16.12 & 2.505 & 25 \\
\hline \multicolumn{2}{|c|}{ total } & 16.08 & 2.221 & 50 \\
\hline $\mathrm{C} 1$ & 1.00 & 16.20 & 2.517 & 25 \\
\hline \multicolumn{2}{|c|}{2.00} & 16.96 & 2.606 & 25 \\
\hline \multicolumn{2}{|c|}{ total } & 16.08 & 2.538 & 50 \\
\hline
\end{tabular}

According to the information in Table 2, the mean scores of the control group which did not experience peer review method and those of the experimental group ranged between 15.48 and 16.68 and 16.04 and 18.28, respectively. 
Table 3 displays the multivariate test (a developed kind of ANOVA) conducted to observe the difference between the students' performances in both groups. The researcher used Wilks' Lambda method to measure the significance and values in both groups.

Table 3. Differences between the students' performance in both groups

\begin{tabular}{|c|l|l|l|l|l|}
\hline Effect & Value & F & $\begin{array}{l}\text { Hypothesis } \\
\text { df }\end{array}$ & $\begin{array}{l}\text { Error } \\
\text { df }\end{array}$ & Sig \\
\hline FACTOR1 Pillai's Trace & .584 & $6.242 \mathrm{a}$ & 9.000 & 40.000 & .000 \\
Wilks'Lambda & .416 & $6.242 \mathrm{a}$ & 9.000 & 40.000 & .000 \\
Hotel ling's trace & 1.404 & $6.242 \mathrm{a}$ & 9.000 & 40.000 & .000 \\
Roy's largest Root & 1.404 & $6.242 \mathrm{a}$ & 9.000 & 40.000 & .000 \\
\hline FACTOR1*GRP & .303 & $1.928 \mathrm{a}$ & 9.000 & 40.000 & .075 \\
Pillai'sTrace & .697 & $1.928 \mathrm{a}$ & 9.000 & 40.000 & .075 \\
Wilks'Lambda & .434 & $1.928 \mathrm{a}$ & 9.000 & 40.000 & .075 \\
Hotel ling's trace & .434 & $1.928 \mathrm{a}$ & 9.000 & 40.000 & .075 \\
Roy's largest Root & & & & & \\
\hline
\end{tabular}

The results of the multivariate test presented in Table 3 reveal that the values and the differences in the experimental group are statistically significant. Although the analysis shows the difference in the control group, it is neither consistent nor statistically significant.

\section{Discussion}

Both quantitative and qualitative analyses of students' comments after the experiment showed that students, as reviewers, benefited from this training regarding writing improvement, confidence build-up, language acquisition and metacognitive strategy use. Likewise, student writers were able to approach topics of interest to them from multiple perspectives On the other hand, the quantitative analysis of the data revealed the positive effect of peer review method on EFL students' writing skill, indicating that the learners engaged in this interactive method were motivated to write more essays and enjoy writing. The quality, consistency, and grades of the final papers were significantly improved. The mean scores of the experimental group in the first experience shifted from 16.20 to 18.28 in the last experiment, but this shift for the control group was ranged from 15.96 to 16.40 . 
Six pair wise comparison samples of the two groups (GRP 1 stands for experimental and GPR 2 stands for the control group) were run by repeated measurement design in the form of Tables. These samples are presented to compare the significance of the individual factor in the experimental group with factors in the control group and also that of the control group one at a time. These samples indicate that although some improvement is made in the control group, unlike that of the experiment group, it is not statistically significant.

At the end of the term, a survey of the students' response to the multiple-test questionnaire used to assess the students' opinions about specific aspects of the peer review method revealed that one hundred percent of the responses to the questions indicated that the students gained from the peer review practice conducted by them.

\section{Conclusion}

As a conclusion, this study focused on the writing progress and perception of EFL students' through peer review method. It was found that not only did students enjoy the process and product, but also a significant development and change was observed in their writing skill. The peer review process engaged the students in frequent reading and writing, fostered their critical reading and reflection, sharpened their writing knowledge and skills, helped them to manage their learning schedule, increased their motivation and joy of writing, and promoted their information literacy. Moreover, the peer review product demonstrated their achievement of ownership and authorship. The results indicated that students achieved autonomy in writing, wrote more frequently and accurately, and most importantly, felt empowered as writers. In general, having such a curriculum was proved as a worthwhile endeavor to undertake in educational settings.

Although peer response remains an important source of giving feedback in many writing courses, as well as ours, there is clearly a need for further investigation to conform the effectiveness of peer review as an effective means of improving L2 writing.

\section{Acknowledgment}

The authors would like to thank the two anonymous reviewers for careful review of our manuscript and providing us with their comments and suggestion to improve the quality of the manuscript. 


\section{References and notes:}

Ali-Grami, G. M. (2010). The effects of integrating peer feedback into university-level ESL writing curriculum: A comparative study in a Saudi context. Unpublished doctoral dissertation, Newcastle University. Retrieved from https://theses. ncl.ac.uk/dspace/ handle/10443/933.

Al-Jamal, D. (2009). The impact of peer response in enhancing ninth grader's writing skill. Journal of Educational \& Psychological Sciences, 1(1), 13-40. Retrieved from libback.uqu.edu.sa/hipres/MAGZ/3200020-8.pdf

Amores, M.J., (1997). Peer Review as a Motivating Device in the Training of Writing.Retrieved from www.questia.com/PM.qst?a=o\&se=gglsc \&d=5001505442.

Berge, Z.L., (1999) .Facilitating Computer Conferencing. Recommendation From the Field. Educational Tecnology, 35(1), 22-30.

Caulk, N. (1994). Using peer feedback in the writing class. ELT Journal, 59(1), 23-30.

Corbin, B. (2012). Improving L2 peer-feedback. Retrieved from www.bryancorbin.net/. ../2012/.../Improving-L2-P

Cumming, A. (2001). ESL/EFL instructors' practices for writing assessment. Language Testing, 18(2), 207-224.

Dempsey, M. S., Pytlikzillig, L. M., \& Burning, R. H. (2009). Helping pre-service teachers learn to asses writing: Practice and feedback in a web-based environment. Assessing Writing, 1, 38-61.

Farrah, M (2012). The impact of peer feedback on improving the writing skills among Hebron university students. An-Najah Uni.J. Res. (Humanities), 26(1), 180-210.

Gao, J., (2007). Teaching Writing in Chinese Universities: Finding an Eclectic Approach. Asian EFL Journal, 20(2), 285-297.

Guerrero, M. \& Villamil, O. S. (1994). Social-cognitive dimensions of interaction in L2 peer revision. The Modern Language Journal, 78, 484-496.

Harmer, J. (2004). Research on peer review Journal of Second Language Writing. UK: Harlow, Essex.

Hedge, T. (1988). Writing Simple Poems; Oxford: Oxford University Press. Cambridge: Cambridge University Press. Retrieved from: www.britishcouncil.org/portugalie2006s-david-hill.pdf

Hedgcock, J., \& Lefkowitz, N., (1992). Collaborative oral/aural revision in foreign language writing instruction. Journal of Second Language Writing, 1(3), 255- 276.

Horowitz, M. (1986). What Professors Actually Require: Academic Tasks for the ESL Classroom. TESOL Quarterly, 20(3), 445-462.

$\mathrm{Hu}, \mathrm{G}$. (2005). Using peer review with Chinese ESL student writers. Language Teaching Research, 9(3), 321-342.

Hyland, F. (2000). ESL writers and feedback: Giving more autonomy to students. Language Teaching Research, 4, 33-54 
Hyland, K. \& Hyland, F. (2006). Contexts and issues in feedback on L2 writing: An introduction. In K. Hyland \& F. Hyland. Feedback in second language writing: Context and issues (pp. 1-19), Cambridge: Cambridge University Press.

Jacobs, H. (1989). Interdisciplinary Curriculum: Design anImplementation.. Alexandria, VA: Association for Supervision and Curriculum Development.

Kamimura, T. (2006). Effects of peer feedback on ESL student writers at different levels of English proficiency: A Japanese context. TESL Canada Journal, 23(2), 12-39.

Keh, C.L. (1990). 'Feedback in the writing process: A model and methods for implementation. ELF Journal, 44(4), 294 -304.

Leki, I. (1990). Potential problems with peer responding in ESL writing classes. CATESOL Journal, 3, 5-19.

Levine, A., Oded, B., Connor, U., \& Asons, I. (2002, December). Variation in EFL-ESL peer response. TESL-EJ: Teaching English as a Second or Foreign Language, 6(3). Retrieved from http://cwp60.berkeley.edu:16080/TESL-EJ/ej23/a1.html

Kim, Y. and Kim, J. (2005). Teaching Korean University Writing Class: Balancing the process and the genre

approach. Asian EFL journal 7, (2) 5.

Lim, L., \& Jacobs, H. (2001). Feedback in Second Language Writing. Cambridge University Press; Retrieved from:cambridge.org/us/catalogue/catalogue.asp? isbn= $9780521672580 \& s s=e x c-39 k-$ Cached.

Min, H. T. (2006). The effects of trained peer review on EFL students' revision types and writing quality. Journal of Second Language Writing, 15, 118-141.

Moffett, J. (1983). Assessment and Evaluation. Clearinghouse Universidad Nacional de Colombia, Ciudad Universitaria, Departmento de Lenguas extranjeras.

Murphey, T. (2000). Encouraging Critical Collaborative Autonomy. Nanzan University Articles, 22(2).

Nelson, G. \& Murphy, J. (1993). Peer response groups: Do L2 writers use peer comments in revising their drafts? TESOL Quarterly, 27(1), 135-142.

O'Brien, T. (2004). Writing in a foreign language: teaching and learning. Language Teaching,37(1), 1-28.

Ohta, A. (1995). Applying sociocultural theory to an analysis of learner discourse: earnerlearner collaborative interaction in the zone of proximal development. Issues in Applied Linguistics, 6(2), 93-121.

O'Muircheartaigh, S. (1990). Given Feedback on Students' Written Work. ELTJ ,44, 1-12.

Raimes, A. (1993). Out of the woods: Emerging traditions in the teaching of writing. TESOL Quarterly, 25, 407- 430.

Reichelt, M.(1999). Toward a more comprehensive view of L2 writing: Foreign language writing in the U.S. Journal of Second Language Writing, 8(2), 181- 204.

Rollinson, P. (2004). Thinking about Peer Review. Oxford: Oxford University Press.

Sengupta, S. (2000). An investigation into the effects of revision strategy instruction on L2 secondary school learners. System, 28(1), 97- 113.

Srichanyachon, N. (2012). An investigation of university EFL students' attitudes toward teacher and peer feedback. Educational Research \& Review, 7(26), 558-562. 
Tribble, C. (1996). The use of a process-oriented approach to facilitate the planning and production stages of writing for adult students of English as a Foreign or Second Language by Nicola Holmes. ELT Journal, 54(2), 153-160.

White, R., \& Arndt, V. (1991). Process Writing. London: Longman.

\title{
Summary
}

\section{The Effect of Peer Review on Writing Skill of EFL Students}

\author{
Nasrin Shokrpour, \\ Shiraz University of Medical Sciences, Shiraz, Iran \\ Nikta Keshavarz, \\ Freelance, Iran

\section{Seyed Mohammad Jafari Shiraz University of Medical Sciences, Shiraz, Iran}

Today more attention has been paid to peer-feedback/evaluation of students' compositions at different levels. As such, the present study aims at investigating the interaction patterns among EFL learners, the effects of peer review techniques on improving the learners' writing skill, and also the motivation aroused by writing in a synchronous writing environment of an EFL context. Fifty EFL students at the intermediate level were enrolled and randomly divided into two experimental and control groups. During a three-month period, both groups were instructed writing. The control group received the traditional teacher-correction/feedback procedure whereas the experimental group was provided with a one-hour of instruction on peer review at the beginning of the term and peer review process was run in this class. The data were collected using a background questionnaire, a pre-test and a post-test for language proficiency and writing skill, a peer response sheet, writing criteria and guideline sheet, and a topic list sheet.

The results of the study indicated that the writings of the students in the experimental group improved more than those in the control group. Also, those engaged in peer review method were motivated to write more essays and enjoyed writing. It was concluded that peer review provides learners with an authentic audience, increases the students' motivation for writing and enables them to receive different views on their writing.

Keywords: Peer Response, EFL Students, Writing improvement 